\title{
Experimental and natural cathodoluminescence in the shell of Crassostrea gigas from Thau lagoon (France): ecological and environmental implications
}

\author{
D. Langlet ${ }^{1,4 *}$, M. Alunno-Bruscia ${ }^{2,5}$, M. Rafélis ${ }^{1}$, M. $\operatorname{Renard}^{1}$, M. Roux ${ }^{3}$, \\ E. Schein ${ }^{3}$, D. Buestel ${ }^{2,6}$ \\ ${ }^{1}$ JE Biominéralisations \& Paléoenvironnements, FRE CNRS 2400 Case 116, Université Pierre \& Marie Curie, \\ 4 Place Jussieu, 75252 Paris Cedex 05, France \\ ${ }^{2}$ IFREMER-LCM (Laboratoire Conchylicole de Méditerranée), BP 171, 34200 Sète Cedex, France \\ ${ }^{3}$ Laboratoire des Sciences de la Terre, Université de Reims, Centre de Recherches sur l'Environnement et l'Agronomie, \\ UMR CNRS 5561, Biogéosciences, 2 Esplanade Roland Garros, 51100 Reims, France \\ ${ }^{4}$ Present address: Section de Pétrographie-Minéralogie-Géochimie, Musée Royal de l'Afrique Centrale, \\ Leuvensesteenweg 13, 3080 Tervuren, Belgium \\ ${ }^{5}$ Present address: CRELA (Centre de Recherche sur les Ecosystèmes Littoraux Anthropisés ), UMR 6217 CNRS, \\ IFREMER \& Université de La Rochelle, Place du Séminaire, BP 5, 17137 L'Houmeau, France \\ ${ }^{6}$ Present address: IFREMER-COP (Centre Océanologique du Pacifique), BP 7004, 98719 Taravao, Tahiti, French Polynesia
}

\begin{abstract}
We present a cathodoluminescence (CL) study of growth layer deposition in the shell of the oyster Crassostrea gigas. CL is based on the physical properties of lattice-bound manganese $\left(\mathrm{Mn}^{2+}\right)$, which is the main activator in calcium carbonate. Our study involved chemical marking by immersing individuals in seawater to which manganese chloride had been added, and subsequent reading of the shell with CL microscopy coupled with numeric treatment of microphotographs; CL emission was analyzed using a scanning electron microscope coupled to a spectrometer. Since the marking did not harm the oysters, repeated markings were possible, allowing validation of the inferences made from analysis of the shell rings. Oysters reared in a French Mediterranean lagoon (Thau lagoon) were marked in June and October 1999, i.e. at the beginning and end of the main shell growth period, respectively. In a few specimens sacrificed $24 \mathrm{~h}$ immediately after marking, we observed a bright marking line, suggesting rapid coprecipitation of $\mathrm{Mn}^{2+}$. In oysters collected from March to July 2000, we found 3 luminescent lines (with an emission peak at $620 \mathrm{~nm}$ peak) that corresponded to the 3 successive markings. The shells also exhibited weak background $\mathrm{Mn}^{2+}$-induced luminescence, which contrasted with the marking lines both in intensity and color. This background signal varied in intensity over time at 3 distinct scales, i.e. seasonal and daily scales plus an intermediate scale that might reflect tidal patterns. The luminescence intensity was clearly positively correlated with seawater temperature. We postulate that the temperature of the lagoon, combined with abiotic and biotic factors, may control both $\mathrm{Mn}^{2+}$ uptake by the bivalve through a stimulation of biomineralization processes, and $\mathrm{Mn}^{2+}$ bioavailability in water through biogeochemical processes. Our study confirmed the usefulness of Mn marking coupled with CL analysis to reveal (1) the complex functioning of the mantle epithelium with respect to carbonate deposition on a microscale, and (2) the relationship between the bivalve and its environment.
\end{abstract}

KEY WORDS: Oyster - Cathodoluminescence $\cdot$ Shell growth $\cdot$ Carbonate biomineralization · Manganese marking $\cdot$ Mediterranean lagoon

\section{INTRODUCTION}

The shell of bivalves grows through deposition of successive layers of carbonate material. External sources and mantle secretions contribute to the chemi- cal signature of the extrapallial fluid from which the shell is produced (Wilbur \& Saleuddin 1983). Analysis of the growth patterns or the geochemical composition of shells should thus provide information about biological processes (Rosenberg \& Hugues 1991, Lorrain et 
al. 2005) and also about the chemical properties of the environmental water during growth. Numerous studies have shown that bivalve shells can be useful in ecological studies and in long-term studies concerning, for example, climate or paleoenvironmental reconstruction (Schein et al. 1991, Surge et al. 2003, Strom et al. 2004).

Among marine bivalves, oysters from the genus Crassostrea are particularly suitable for shell analysis because of their common occurrence in the intertidal zone of coastal and estuary areas along a wide latitudinal and geological gradient (Stenzel 1971). Because of their ubiquity, Crassostrea spp. should provide records for a large variety of environments and enable longterm monitoring of ecological conditions.

The main challenge in the use of growth layers as chemical records is to express the results of the analysis as a function of time. For this purpose, growth marks identified as periodic features (e.g. annual lines) have been used to determine age, seasonality and growth rates of various bivalve species (e.g. Rhoads \& Lutz 1980, Richardson et al. 1993). In Crassostrea spp. shells, the succession of irregular external blades on the valves suggests a rhythmic growth pattern, but the growth interval represented by this irregular pattern has not yet been determined. However, both millimetric undulations and very thin rings $<5 \mu \mathrm{m}$ have been described for the ligamental area of the hinge of C. virginica by Palmer \& Carriker (1979), who estimated the periodicity of shell-band deposition at about 1 ring per tidal cycle in the field, and about 4 or 5 rings $\mathrm{d}^{-1}$ in the laboratory. Similar undulations and rings were also reported for C. gigas by Piquet (1994), but unfortunately no internal growth lines were found in radial sections of the hinge of $C$. virginica (Palmer \& Carriker 1979, Carriker et al. 1980a). The direction of the growth axis was only indicated by the spatial arrangement of chalky lenticular areas and translucent bands of foliated calcite (see Carriker et al. 1980a). Therefore, determining growth patterns of Crassostrea spp. shells by classical methods based on sclerochronologic markers (Rhoads \& Lutz 1980) seems difficult.

To estimate shell growth rate from growth bands, a number of alternative methods based on the fixation of chemical elements in the shell growth layers have been developed. Experimental enrichment with fluorochromes (Day et al. 1995, Kaehler \& McQuaid 1999, Sato-Okoshi \& Okoshi 2002) or strontium (Peck et al. 1996, Fujikura et al. 2003) creates bright artificial lines when observed under fluorescence or scanning electron microscopy. Another method consists of using carbonate manganese-induced cathodoluminescence (CL). CL is the emission of visible light during excitement by an external source of energy (electron bombardment) and results from interactions between a light-emitting center and its atomic environment inside the crystal lattice. Lattice-bound manganese $\left(\mathrm{Mn}^{2+}\right)$ is the main activator of luminescence in carbonates (see review by Pagel et al. 2000). Luminescence induced by natural levels of manganese derived from the ambient environment has been detected in aragonitic and calcitic shells of mollusks (see review in Barbin 2000). Marking experiments using dissolved manganese $\left(\mathrm{Mn}^{2+}\right)$ and CL microscopy have been used to investigate shell mineralization in the Japanese oyster Crassostrea gigas (Piquet 1994) and the black-lip abalone Haliotis rubra (Hawkes et al. 1996).

In the present study, using the Japanese oyster Crassostrea gigas reared in a Mediterranean lagoon we tested a method that combines $\mathrm{Mn}^{2+}$-marking of the microgrowth layers in the shell of a marine bivalve with a numeric treatment of CL microphotographs. This allowed us to create a temporal framework in which the distribution of $\mathrm{Mn}^{2+}$ in the shell was analyzed at high spatial resolution in relation to shell growth processes and environmental fluctuations.

\section{MATERIALS AND METHODS}

Study area. Thau lagoon is located on the French Mediterranean coast near Sète (Fig. 1). The lagoon is $19.5 \mathrm{~km}$ long $\times 4.5 \mathrm{~km}$ wide, and is $5 \mathrm{~m}$ deep on average. It is connected to the Mediterranean Sea by the Sète canal; other connections are negligible. Thau lagoon is a semi-confined ecosystem with a long water

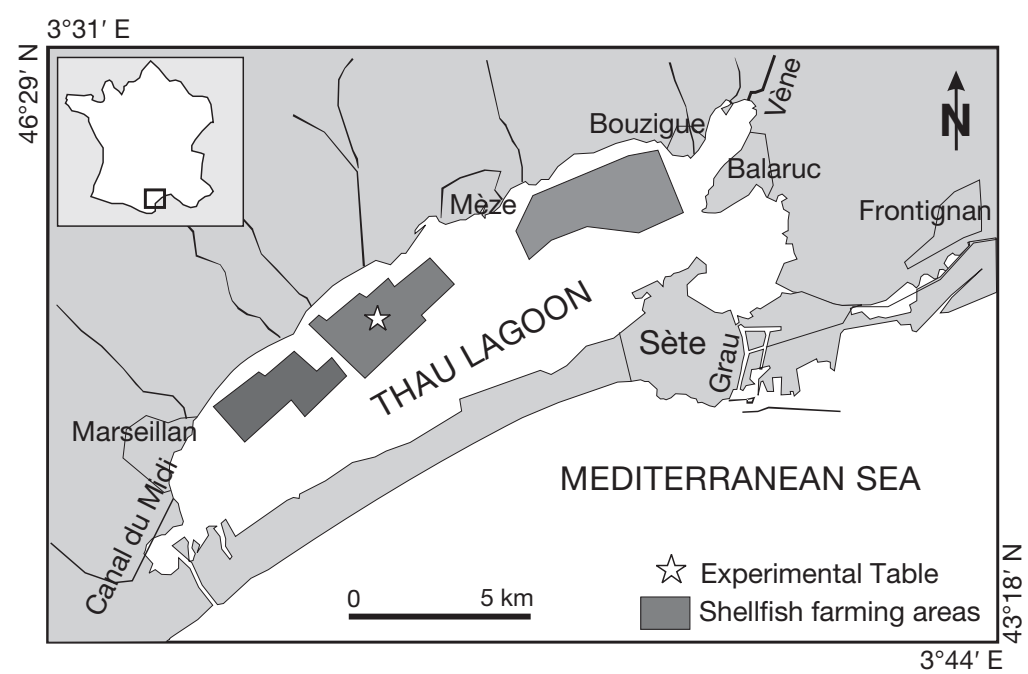

Fig. 1. Thau lagoon. (论): position of experimental Crassostreas gigas culture table 
residence time due to the low tidal range of about $20 \mathrm{~cm}$ in Sète harbor. It receives variable, but occasionally strong, freshwater discharge from small streams (Petelet et al. 1997). The lagoon supports a large standing stock of bivalves (mussels and oysters), ranging from 14000 to $20000 \mathrm{t} \mathrm{yr}^{-1}$ (Gangnery et al. 2003). The oyster Crassostrea gigas accounts for about $75 \%$ of the total cultured biomass (Gangnery et al. 2003). In Thau lagoon, oysters are fixed on ropes hanging from fixed tables (see Fig. 2 in Gangnery et al. 2003). Anthropogenic impacts on Thau lagoon comprise the harbor activities in Sète, agricultural activities, e.g. wine and melon farming, and heavy tourism during the summer. The main source of $\mathrm{Mn}$ in Thau lagoon is from the particulate load of rivers, especially during fall and spring (Pena \& Picot 1991, Petelet et al. 1997).

Hydrological parameters - water temperature $\left(T,{ }^{\circ} \mathrm{C}\right)$, salinity ( $\mathrm{S}, \mathrm{PSU})$, and dissolved oxygen concentration $\left(\mathrm{O}_{2}, \%\right)$ were measured every second week with a SOLOMAT WTW-LF-197S probe at 2 depths $(1.0 \mathrm{~m}$ below the surface and $0.5 \mathrm{~m}$ above the bottom) and at 5 points around a single oyster table (Alunno-Bruscia et al. 2001). Moreover, from April to November 1999, temperature was recorded hourly at $2 \mathrm{~m}$ depth on the culture table with a MICREL probe.

Manganese marking and shell preparation. From 15 to 18 March 1999, spat oysters Crassostrea gigas from SATMAR hatchery (pre-grown in Penzé, Brittany, France, for $18 \mathrm{mo}$ ) were glued onto ropes, which were tied on a culture table in Thau lagoon (Fig. 1) for $15 \mathrm{mo}$ until July 2000 (Alunno-Bruscia et al. 2001). On 15 June 1999, 8 randomly selected ropes were detached from the culture table and brought to the laboratory, care being taken to avoid oyster fall-off. On these ropes, a $0.45 \mathrm{~m}$ section (with about 12 oysters) between 1.15 and $1.60 \mathrm{~m}$ below the water surface was used for marking. Oysters were marked by immersion for $4 \mathrm{~h}$ in a $500 \mathrm{l}$ tank filled with seawater and manganese chloride tetrahydrate $\left(\mathrm{MnCl}_{2}, 4 \mathrm{H}_{2} \mathrm{O}\right)$, similarly to the method described by Hawkes et al. (1996). ( $\left.\mathrm{MnCl}_{2}, 4 \mathrm{H}_{2} \mathrm{O}\right)$ was added at a concentration of $90 \mathrm{mg} \mathrm{l}^{-1}$, i.e. $\left[\mathrm{Mn}^{2+}\right]=25 \mathrm{ppm}$. After marking, the ropes were tagged and quickly replaced onto the culture table. The whole process was repeated on 18 June and 21 October, using the same rope segments. Seawater temperature was 22.3 and $23.0^{\circ} \mathrm{C}$ on 15 and 18 June, respectively and $17.3^{\circ} \mathrm{C}$ on 21 October. No variation in water temperature was measured in the tank during the marking periods. Oysters exhibited active filtration only a few minutes after the marking process began. No effect of marking on the oysters' survival was observed. Oysters were sampled on 5 occasions (20 in October 1999 and May 2000; 10 in March, April and July 2000, respectively), and 5 individuals from each sampling were prepared for analysis (see next paragraph for shell preparation). In addition, a marking test $\left(\left[\mathrm{Mn}^{2+}\right]=\right.$ $25 \mathrm{ppm}$ for $4 \mathrm{~h}$ at $18.5^{\circ} \mathrm{C}$ ) was performed on 10 oysters collected $24 \mathrm{~h}$ after marking in order to estimate the delay between experimental immersion and appearance of the marker in the shells.

Marked oysters were sacrificed and their flesh carefully removed. Thick sections were removed from the hinge and the ventral margin of the right valve (Fig. 2). Each section was placed face down in a plastic mold and embedded in polyester resin. Once hardened, the surface of the resin blocks was ground flat, wet-polished and glued onto a glass slide before being sliced. Finally, the section surface was ground and wet polished with polishing suspensions of decreasing grain

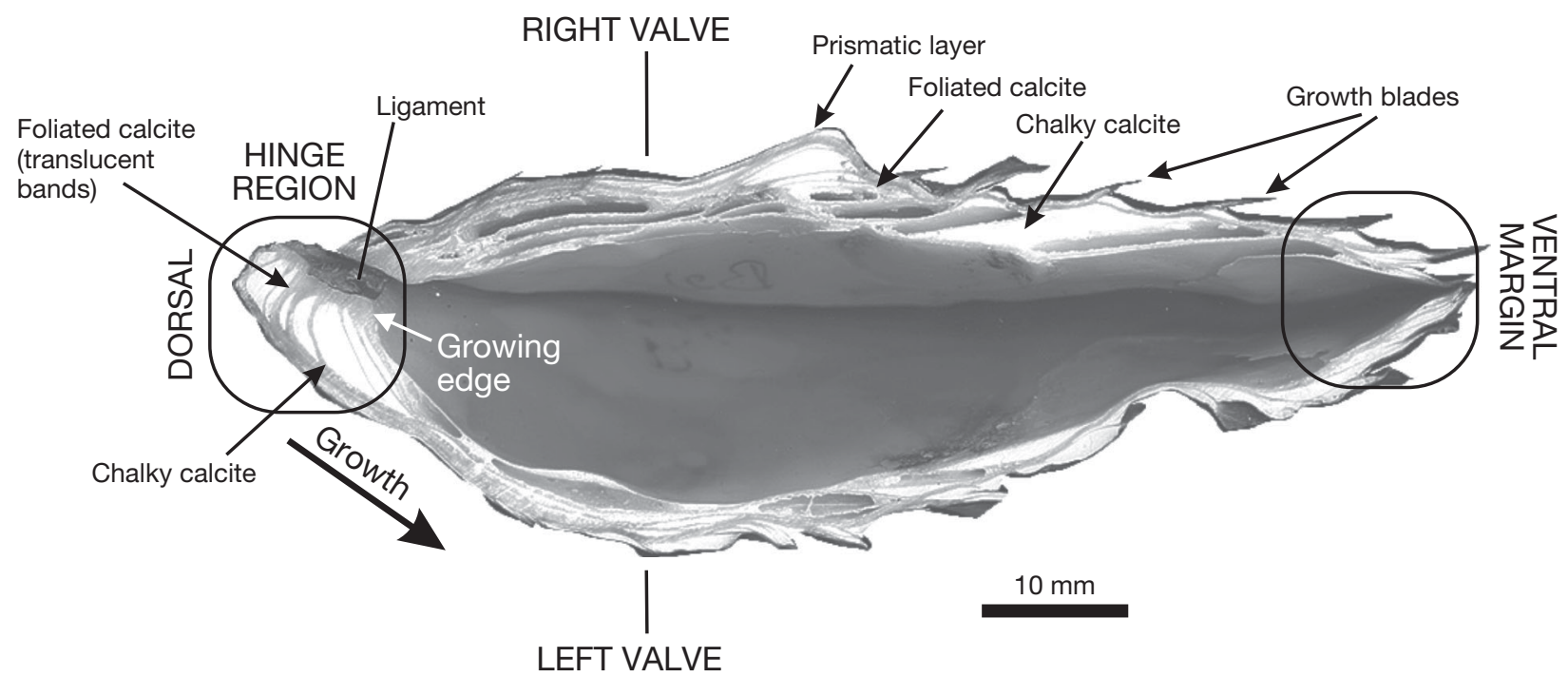

Fig. 2. Crassostrea gigas. Radial section through longest shell axis. Most of shell structure is calcitic. Polished sections for cathodoluminescence analysis were obtained from hinge and ventral margin of shell 
size (down to $1 \mu \mathrm{m}$ ). Using this protocol, we prepared 35 shells (including the 10 specimens used in the marking test) for CL analysis.

Cathodoluminescence analysis. The shell of Crassostrea gigas consists of calcite and aragonite, 2 polymorphs of $\mathrm{CaCO}_{3}$ (Stenzel 1963). When exposed to an electron beam, pure calcite presents a weak dark-blue luminescence called intrinsic luminescence (emission spectrum centered around 350 to $400 \mathrm{~nm}$ ). The presence of $\mathrm{Mn}^{2+}$ in the calcite lattice results in a brighter luminescence, and a specific emission spectrum with a peak at $620 \mathrm{~nm}$ (see Pagel et al. 2000 for review) corresponding to yellow, orange or orange-red. In aragonite, the substitution of $\mathrm{Ca}^{2+}$ by $\mathrm{Mn}^{2+}$ leads to yellowgreen luminescence, with an emission peak at $540 \mathrm{~nm}$. Variations in the luminescence intensity (LI) are mainly related to the proportion of activators (i.e. $\mathrm{Mn}^{2+}$ ): the brighter the luminescence, the higher the $\mathrm{Mn}^{2+}$ concentration (El Ali et al. 1993, Rafélis et al. 2000).

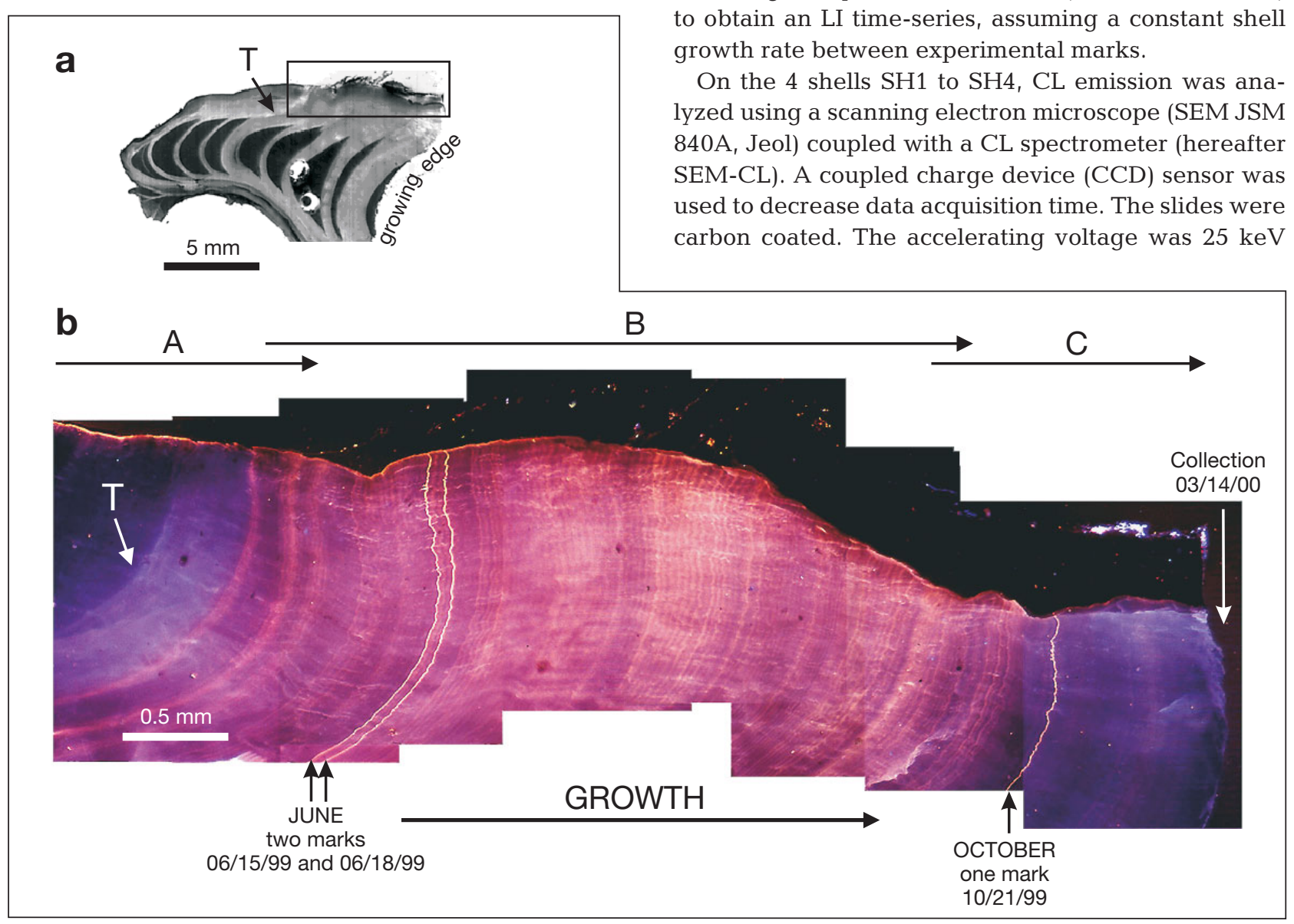

Fig. 3. Crassostrea gigas. (a) Microphotograph under transmitted light of polished cross-section from hinge of Shell SH1. Translucent layer $(\mathrm{T})$ indicates change in environmental conditions affecting growth, i.e. with transplantation from Britanny to Thau lagoon in March 1999 (boxed section = polished area illustrated in b); (b) cathodoluminescence microphotograph of specific area from polished section in (a), showing 3 bright luminescent lines induced by selective Mn marking, and large areas with contrasting luminescence due to more diffuse natural luminescence. A, B, C: 3 successive periods; (A) winter/spring 1999, (B) summer 1999, (C) fall 1999 to spring 2000. Dates on figure are mm/dd/yy
The color and intensity of the CL emission were observed with a cold cathode coupled with an optical $15 \mathrm{keV}$ and 0.3 to $0.4 \mathrm{~mA}$ current under a $60 \mu$ torr vacuum provided optimal conditions for visual observation of CL under an optic microscope. Pictures were done at magnifications of 10 to $20 \times$, with Kodak 800 ASA (Ektachrome P1600x), and required exposure times of 15 to $60 \mathrm{~s}$. Time exposure was kept constant for each section. For 4 specimens (labeled SH1 to SH4), successive CL-microphotographs were assembled precisely to provide a detailed panorama of the hinge. The resulting pictures were digitized. SH1 and SH2 were collected in March 2000, SH3 and SH4 in April and July 2000, respectively. For each digitized picture, a profile of the spatial variations in luminescence (expressed in arbitrary gray-scale units) along a growth axis was obtained using NIH Image software (http:// rsb.info.nih.gov/ij/). The temporal scale was introduced using Analyseries 1.1 software (Paillard et al. 1996) obtain an LI time-series, assuming a constant shell On the 4 shells SH1 to SH4, CL emission was analyzed using a scanning electron microscope (SEM JSM 840A, Jeol) coupled with a CL spectrometer (hereafter used to decrease data acquisition time. The slides were carbon coated. The accelerating voltage was $25 \mathrm{keV}$ microscope (Technosyn Mark II). A beam energy of 
with a $0.1 \mu \mathrm{A}$ current, and the spectrometer slit was fixed at $1 \mathrm{~mm}$ (allowing a $1 \mathrm{~nm}$ resolution at $500 \mathrm{~nm}$ with a linear dispersion of $8 \mathrm{~nm}$ ). Spectra were collected between 300 and $800 \mathrm{~nm}$ (time acquisition = $2 \mathrm{~s}$ ) at $400 \times$ magnification (analytic area: $300 \times 200 \mu \mathrm{m}$ ). A $1000 \times$ magnification was used to focus the analysis on the marking line (analytic area $=200 \times 20 \mu \mathrm{m}$ ). Multiple scans and blank corrections were used to eliminate background noise. Final spectra comprised an average of 10 measures and CL intensity was expressed in arbitrary units (counts $\mathrm{s}^{-1}$ ).

Data analysis. Frequency and regression analyses were carried out.

Frequency analysis: A fast Fourier transformation (FFT) was performed on the 4 discrete detrended (i.e. 5 th order fitted polynomial model) LI time series (N data, separated with a time step $\Delta t$ ) corresponding to the 4 shells SH1, SH2, SH3 and SH4, in order to detect periodicities in the luminescence intensity. The discrete Fourier series, $\gamma(t)$, is defined as

$$
\gamma(t)=a_{0}+\sum_{\mathrm{n}=1}^{N}\left[a_{\mathrm{n}} \cos \left(2 \pi f_{\mathrm{n}} t\right)+b_{\mathrm{n}} \sin \left(2 \pi f_{\mathrm{n}} t\right)\right]
$$

where $a_{0},\left\{a_{\mathrm{n}}, b_{\mathrm{n}}, \mathrm{n}=1, \mathrm{~N}\right\}$ are adjusted parameters, $\mathrm{N}$ being the number of data acquired by image analysis (see Fig. 6), for each discrete frequency $f\left(\mathrm{~d}^{-1}\right)$ investigated. The discrete Fourier transform (DFT) of the series was expressed as a complex number series $G\left(f_{\mathrm{n}}\right)$ $=a_{\mathrm{n}}+i b_{\mathrm{n}}$. The power spectral density was then calculated to estimate the energy at each frequency

$$
S\left(f_{\mathrm{n}}\right)=G\left(f_{\mathrm{n}}\right) \cdot \operatorname{conj}\left[G\left(f_{\mathrm{n}}\right)\right]
$$

where $\operatorname{conj}\left(G\left(f_{\mathrm{n}}\right)\right)$ is the complex-conjugate of $G\left(f_{\mathrm{n}}\right)$. Since the time-series are discrete and truncated, analyses of frequencies were restricted to each frequency domain $\left[(0.5 \mathrm{~N} \Delta t)^{-1}(2 \Delta t)^{-1}\right]$.

Regression analysis: A simple linear regression model was used to relate the water temperature $(T)$ or the oxygen concentration $\left(\mathrm{O}_{2}\right)$ to the LI. Significant regressions among the 4 different shells were compared by analysis of covariance (ANCOVA), first by testing equality of slopes via the interaction between the covariate and the shell factor, and then by testing elevations of lines with homogeneous slopes for equality via the shell factor by removing the interaction term (Huitema 1980).

\section{RESULTS}

\section{Luminescence induced by Mn marking}

Observed under CL-microscopy, shell cross-sections in the hinge of all Mn-marked oysters showed 2 closely-spaced and bright, orange-red luminescent lines (Fig. 3). The emission spectra of these 2 lines
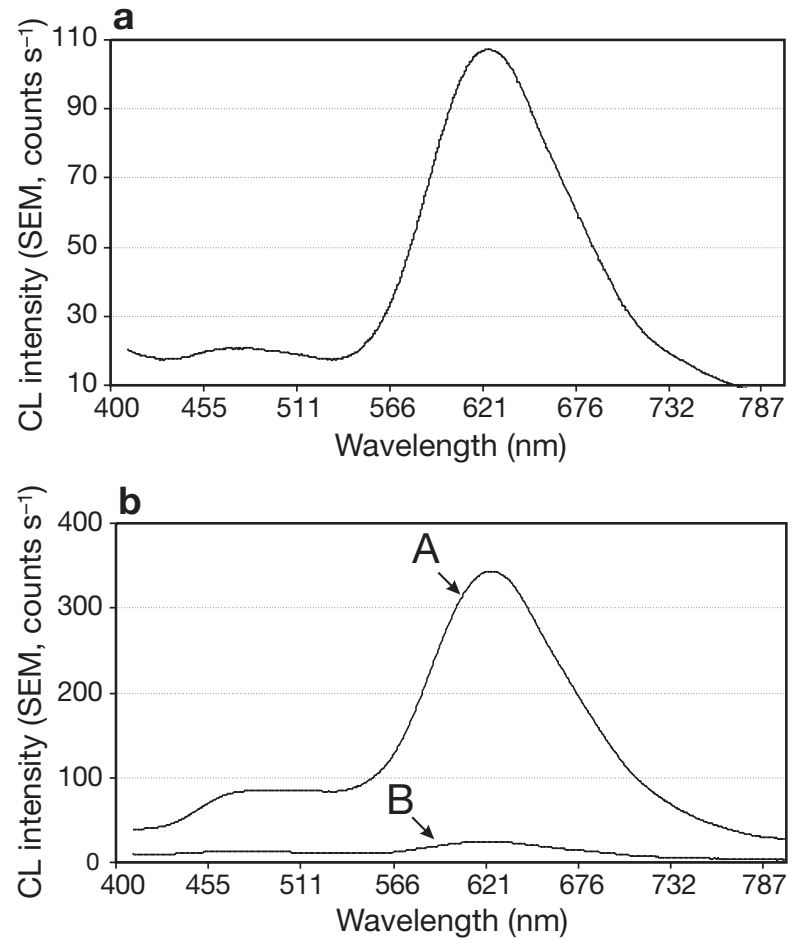

Fig. 4. Crassostrea gigas. Emission spectra obtained by SEMCL on shells relative to (a) 1 of bright luminescent marking lines induced by Mn marking (magnification 1000×, analytic area $200 \times 20 \mu \mathrm{m})$, and (b) areas of bright natural luminescence (orange-red area, Curve A) and of weak natural luminescence (purple-blue area, Curve B) (magnification $400 \times$, analytic area $300 \times 200 \mu \mathrm{m})$

peaked at $620 \mathrm{~nm}$ (Fig. 4a) consistent with manganese-activated luminescence. Thus, these 2 lines correspond to the 2 successive markings on 15 and 18 June 1999. A third, bright-orange luminescent line, with an emission spectrum also centered on $620 \mathrm{~nm}$, was also detectable, but only on 19 of the 25 shells examined (example in Fig. 3), and correspond to the marking on 21 October. The reason as to why about $25 \%$ of the samples did not exhibit the third mark is unclear. The width (and thus visibility) of the marks depends on the growth rate of the oysters, and interindividual variations in growth may explain this result. The mean daily growth rate was estimated to be $0.39 \%$ from May to June $(0.19 \% \mathrm{SD})$ (Alunno-Bruscia et al. 2001) during the period of the 2 first markings (June). It then slightly decreased to $0.25 \%(0.08 \% \mathrm{SD})$ from September to November, when the 3rd marking occurred, and finally reached $0.06 \%$ in winter. Thus, in October, Mn should have been incorporated into the growth layers: the resultant low CL intensity may have been under the detection limit of the 'cold-cathode' technique used in the present study.

Examination of the ventral edge of 10 shells collected $24 \mathrm{~h}$ after marking revealed a thin luminescent line 
followed by a non-luminescent carbonated layer just below the ventral margin (distance $<50 \mu \mathrm{m}$ ), which was visible in all 10 shells. This suggests rapid coprecipitation of $\mathrm{Mn}$ in the shell during the $4 \mathrm{~h}$ marking period, i.e. a short time lag due to metal storage in soft tissues or ionic transport to the shell. Thus, the artificial lines can be considered precise temporal marks.

The luminescent marking lines were visible across the whole shell, from the ventral margin to the hinge (Figs. 3 \& 5), and crossed the limit between the foliated bands (i.e. translucent bands in transmitted light) and the lenses of chalky calcite (dark areas in transmitted light) (Figs. $2 \& 5 \mathrm{a}$ ). The lines were between approximately 5 and $20 \mu \mathrm{m}$ wide, depending on calcite type (wider in the chalky than in the foliated structure; Fig. 5a). Their width could not be estimated easily because of the differences in the optical properties of the 2 microstructures. The spatial layout of calcitic blades is less organized in the chalky (porous structure) than in the foliated microstructure (higher density), resulting in a greater diffraction of light in the former. The distance between the 2 close marking lines was greater in the chalky than in the foliated calcite, in accordance with the deposition of carbonates in the same quantity but of a different density. The marking lines changed in color from orange $(620 \mathrm{~nm}$ peak emission), high intensity, in the hinge (calcite) area to yellow-green $(540 \mathrm{~nm}$ wavelength), lower intensity, in the ligament (partly aragonite) (Fig. 5b). This indicates that the 2 carbonate polymorphs, calcite and aragonite, were secreted simultaneously.

\section{Temporal variations in natural luminescence}

The shells also exhibited natural background luminescence, contrasting with the Mn marking induced luminescence in both intensity and color. The background graded from purple-dark blue to orange-red (Fig. 3b), with an emission spectrum peaking at $620 \mathrm{~nm}$, but with different amplitudes, indicating variation in the concentrations of $\mathrm{Mn}^{2+}$ (Fig. 4b, Curves A and B). Mean Mn concentrations were higher in orange-red areas ( $\approx 15 \mathrm{ppm})$ than in purple-blue areas $(\approx 2.5$ ppm, Langlet 2002). Contrast- ing with the relative uniformity of the dark blue areas, orange-red areas were characterized by alternating bright (i.e. luminescent) and dark (i.e. non-luminescent) lines (Fig. 3b). The distance between 2 bright lines and their CL intensity changed over the year from about 10 to $30 \mu \mathrm{m}$ (Fig. 5c). Below a threshold of $10 \mu \mathrm{m}$, the lines were less distinct because of decreasing CL intensity.

As revealed by the CL-microphotograph (Fig. 3) and the temporal profile of luminescence intensity (Fig. 6), natural luminescence varied over time at 3 distinct scales, identified from the 4 chronological references, the 3 artificial Mn-markings (15 and 18 June, 21 October 1999), and the final sampling (14 March 2000 for Shell SH1). Another mark was consistent with the

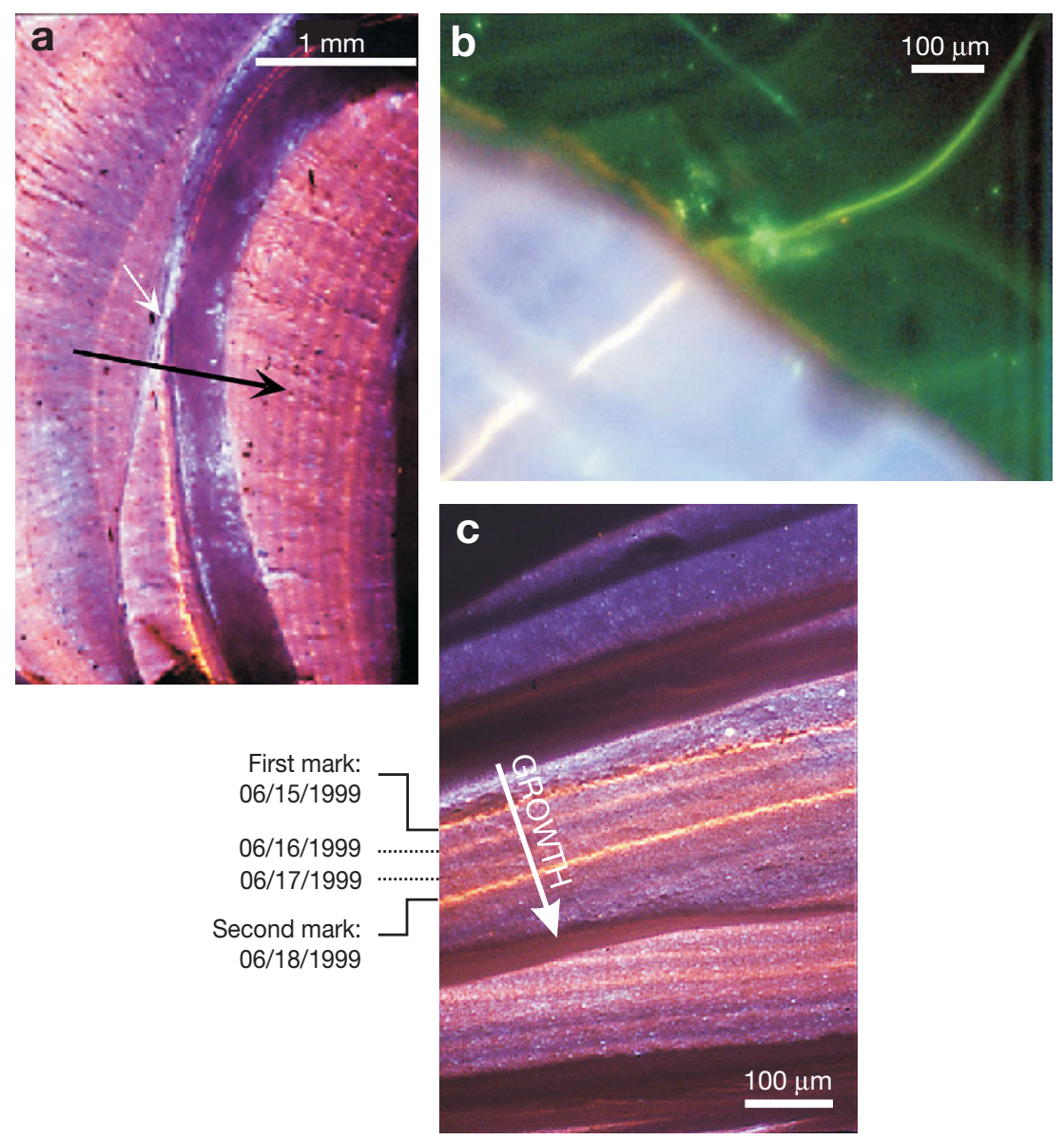

Fig. 5. Crassostrea gigas. Cathodoluminescence microphotographs of polished cross-section from $(a, b)$ hinge and (c) ventral margin of shell. In (a, c) 2 bright luminescent lines induced by Mn marking (15 and 18 June 1999) are clearly visible within contrasting natural luminescence. In (a) white arrow indicates transition between foliated and chalky calcite, black arrow shows growth direction. In (b), marking line corresponding to 21 October 1999 crosses limit between calcitic hinge and aragonitic ligament, and changes color (yellow-green in ligament) and intensity (lower in ligament). Color balance and luminosity were adjusted to highlight natural and experimental luminescence in the ligament. In (c) 2 pairs of lines (1 luminescent/1 non-luminescent) of natural luminescence are visible between the 2 experimental marks (15 and 18 June 1999); each pair may represent a daily growth layer. Dates on figure are $\mathrm{mm} / \mathrm{dd} / \mathrm{yy}$ 


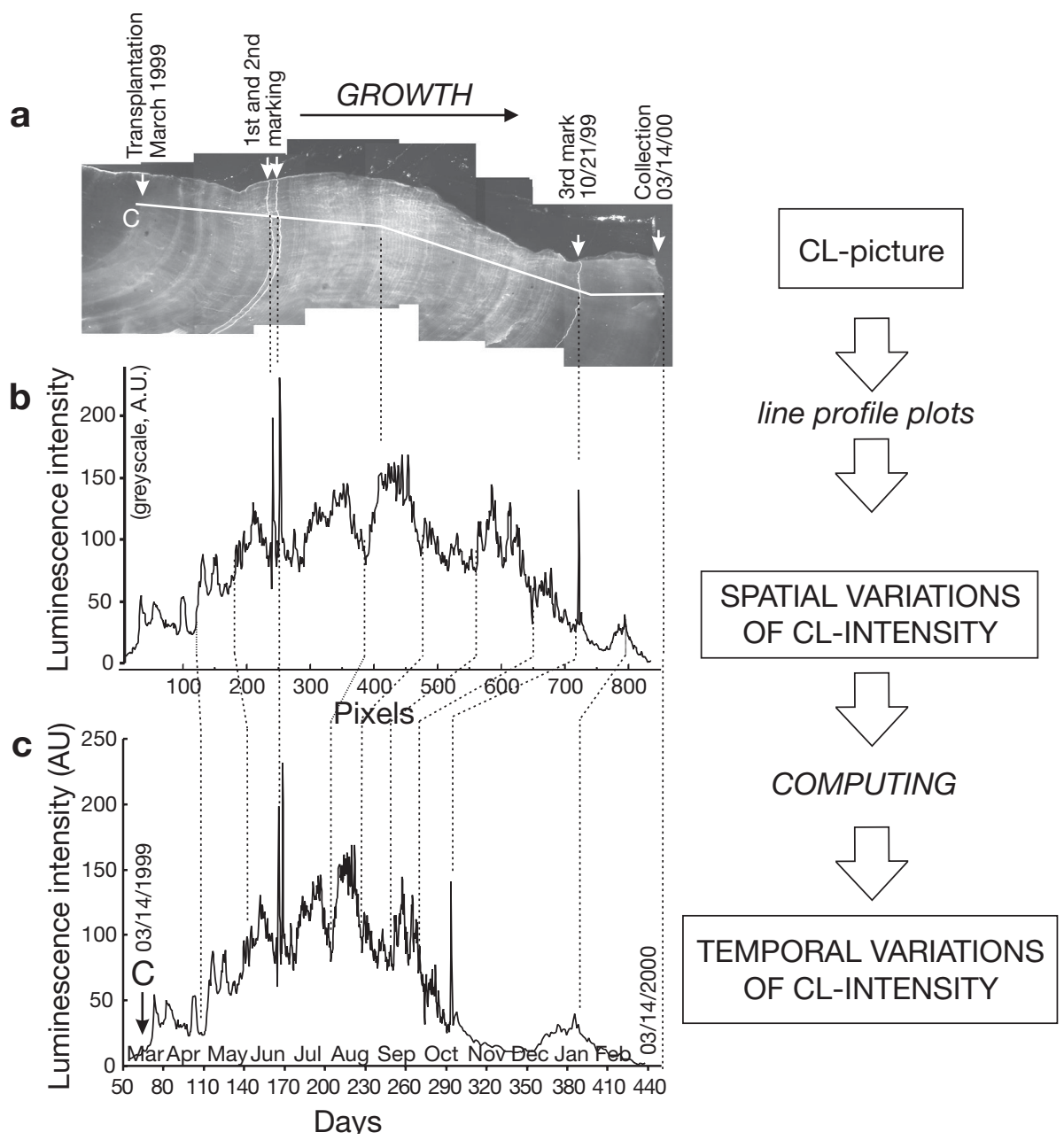

Fig. 6. Crassostrea gigas. (a) Stages for creating and processing temporal (line) profile of luminescence intensities (LI) by digitizing a CLmicrophotograph, followed by (b) digital analysis with NIH Image software along growth axis, resulting in (c) temporal series of LI. We used 5 chronological references to assign dates to each estimated value of LI in (c), the 'natural' marking reflecting oyster transplantation into Thau lagoon between 8 and 18 March 1999; the 3 artificial Mn markings on 15 and 18 June, and on 21 October 1999; and dates for final sampling of oysters in March (Shells SH1, SH2), April (Shell SH3) and July 2000 (Shell SH4). Results are shown for Shell SH1 only, but were similar among all 4 shells. Dates in Graph (c) are $\mathrm{mm} / \mathrm{dd} / \mathrm{yy}$

'transplantation' of the oysters into Thau lagoon (from 15 to 18 March 1999). At a seasonal scale, the highly luminescent (i.e. orange-red) areas (Fig. 3b: Zone B) with the highest LI (Fig. 6b) corresponded to late spring and summer, from April to late September (Fig. 6c); the purple-blue areas (Fig. 3b: Zones A and C) corresponded to fall and winter, from October 1999 to March 2000 (Fig. 6c) when LI was lowest (Fig. 6b; see also Fig. 4b). At an intermediate temporal scale ( $>1 \mathrm{~d}$ ), fluctuations in natural luminescence revealed 6 distinct periodicities of close to $7 \mathrm{~d}$ each, as revealed by spectral analysis of the temporal profiles of the 4 shells SH1, SH2, SH3 and SH4 (Table 1); natural luminescence reached maximum CL intensity in August 1999 (Fig. 6c.), corresponding to the higher Mn concentrations in the shell at that time (21.7 ppm; Langlet 2002). At a daily scale, 2 lines of natural luminescence were clearly visible in all the 25 shells analyzed between the 2 experimental Mn markings in June (Fig. 5c); these 2 lines of natural luminescence were separated from each other and from the 2 bright marking lines by 3 purple-blue lines, and could be attributable to daily growth increments in the shells during the 2 d interval between 15 and 18 June.

\section{Relationship between hydrological parameters (water temperature, dissolved oxygen) and intensity of natural luminescence}

There was a significant correlation between water temperature $(T)$ and luminescence intensity (LI) in the 4 shells analyzed under CL (Fig. 7). LI clearly increased with increasing water temperature, while $T$ exhibited seasonal variations ranging between $6.6^{\circ} \mathrm{C}$ in early November 1999 and $27.2^{\circ} \mathrm{C}$ in August 1999 (Alunno-Bruscia et al. 2001). These results were consistent with the seasonal variation in natural luminescence in the foregoing subsection (see also Fig. 3). Significant regressions of $T$ against LI were obtained for each of the 4 shells (Table 2a). The comparison of these regression lines revealed that slopes and elevations were homogeneous among the shells SH1, SH2 and SH4 (Table 2b), for which a final adjusted model was estimated: $\mathrm{LI}=-43.699+6.604 \cdot T\left(\mathrm{r}^{2}=0.635\right.$; sample size, $N=603$ ). However, the relationship of $T$ with LI in SH3 differed significantly from that of the other 3 shells (Table 2). For any given temperature, LI was not significantly different in SH1, SH2 and SH4; in Shell 
Table 1. Crassostrea gigas. Periods of luminescence intensity (LI) and corresponding power for 4 oyster shells (SH1, SH2, SH3, SH4) from Thau lagoon, obtained by the fast Fourier transformation on discrete detrended (5th order fitted polynomial model) LI time series

\begin{tabular}{|c|c|c|}
\hline Shell & Period (d) & Power \\
\hline SH1 & $\begin{array}{c}96 \\
52 \\
35 \\
22 \\
13 \\
7\end{array}$ & $\begin{array}{l}1.740 .10^{6} \\
1.184 .10^{6} \\
2.215 .10^{6} \\
6.140 .10^{5} \\
2.983 .10^{5} \\
1.579 .10^{5}\end{array}$ \\
\hline $\mathrm{SH} 2$ & $\begin{array}{c}85 \\
50 \\
33 \\
21 \\
13 \\
7\end{array}$ & $\begin{array}{l}2.281 .10^{6} \\
5.439 .10^{5} \\
2.272 .10^{6} \\
5.175 .10^{5} \\
1.140 .10^{5} \\
1.140 .10^{5}\end{array}$ \\
\hline SH3 & $\begin{array}{c}95 \\
52 \\
31 \\
24 \\
14 \\
7\end{array}$ & $\begin{array}{l}9.094 .10^{6} \\
7.339 .10^{6} \\
2.047 .10^{5} \\
5.263 .10^{5} \\
5.526 .10^{5} \\
1.140 .10^{5}\end{array}$ \\
\hline $\mathrm{SH} 4$ & $\begin{array}{c}103 \\
53 \\
35 \\
22 \\
14 \\
7\end{array}$ & $\begin{array}{l}2.061 .10^{6} \\
2.193 .10^{6} \\
5.702 .10^{5} \\
3.860 .10^{5} \\
1.667 .10^{5} \\
1.097 .10^{5}\end{array}$ \\
\hline
\end{tabular}

SH3 and for $T_{\min }<5.8^{\circ} \mathrm{C}$, however, LI was lower than in the other 3 shells, while it was greater than in the 3 other shells for $T_{\max }>13.2^{\circ} \mathrm{C}$. Both $T_{\min }$ and $T_{\max }$ were estimated according to Huitema (1980).

We also found a significant correlation between dissolved oxygen concentration in the water and luminescence intensity for the 4 shells (Table $3 a$ ). $\mathrm{O}_{2}$ concentration is physically linked to the water temperature, and during our experiment we found a significant linear relationship between $\mathrm{O}_{2}$ concentration and $T$ (ordinary least square regression model: $T=$ $-1.516 \cdot \mathrm{O}_{2}+31.287, \mathrm{r}^{2}=0.551, \mathrm{p}=0.001$, $\mathrm{N}=94$ ). Over the study period, $\mathrm{O}_{2}$ concentration was lower during the summer ( $\approx 6.3 \mathrm{ppm}$ on average) than during the fall and winter $(\approx 10.5 \mathrm{ppm})$, and varied between 4.1 and $12.5 \mathrm{ppm}$. Slopes of the regressions of $\mathrm{O}_{2}$ against LI for the 4 shells were clearly negative (Table 3b). Slopes among the 4 shells were homogeneous, with an adjusted common value of -9.480 ; elevations also did not differ significantly among the 4 shells (Table $3 \mathrm{~b}$ ).

\section{DISCUSSION}

\section{Manganese marking method}

Our study clearly showed that $4 \mathrm{~h}$ immersion of Crassostrea gigas in a seawater bath enriched with $\mathrm{Mn}^{2+}$ (25 ppm) at a temperature of 22.3 or $23^{\circ} \mathrm{C}$, led to the incorporation of $\mathrm{Mn}^{2+}$ in the carbonate lattice of oyster shells. This non-invasive marking method is very convenient for many reasons: easy implementation, (relatively low concentration of the marker, high solubility of manganese chloride, short time of exposure), high specificity of the chemical marker (rapid and permanent incorporation of $\mathrm{Mn}^{2+}$ by substituting $\mathrm{Ca}^{2+}$ in the crystal network) and very low cost. Moreover, CL detects the $\mathrm{Mn}^{2+}$ incorporated into the carbonates at low concentrations (<5 ppm) (Barbin 2000, Langlet 2002). The $\mathrm{Mn}^{2+}$ concentration of $25 \mathrm{ppm}$ we used was much higher than the natural levels of manganese in marine environments (from $0.1 \mathrm{ppb}$ to $8 \mathrm{ppb}$ : Hood 1972), and allowed us to obtain a bright luminescent marking band that contrasted with natural luminescence and caused no mortality of the oysters.

Our Mn marking method also revealed that the transfer of $\mathrm{Mn}^{2+}$ from the marking bath to the shell and its incorporation into the calcite lattice (bright luminescent line) occurred very quickly. The lag phase between application of the marker and its expression in the shell was less than $24 \mathrm{~h}$ (a luminescent line was present at the shell margin in specimens collected $24 \mathrm{~h}$ after immersion in the Mn-solution). Thus, each natural luminescent line found between the 2 close experimental marks could be reasonably attributed to daily shell increments (Fig. 5c). Our results also suggested a short period for shell/seawater equilibration after replacing the oysters in the field (no artificial luminescence between 2 close markings), indicating both quick transfer and turnover of this element in the soft

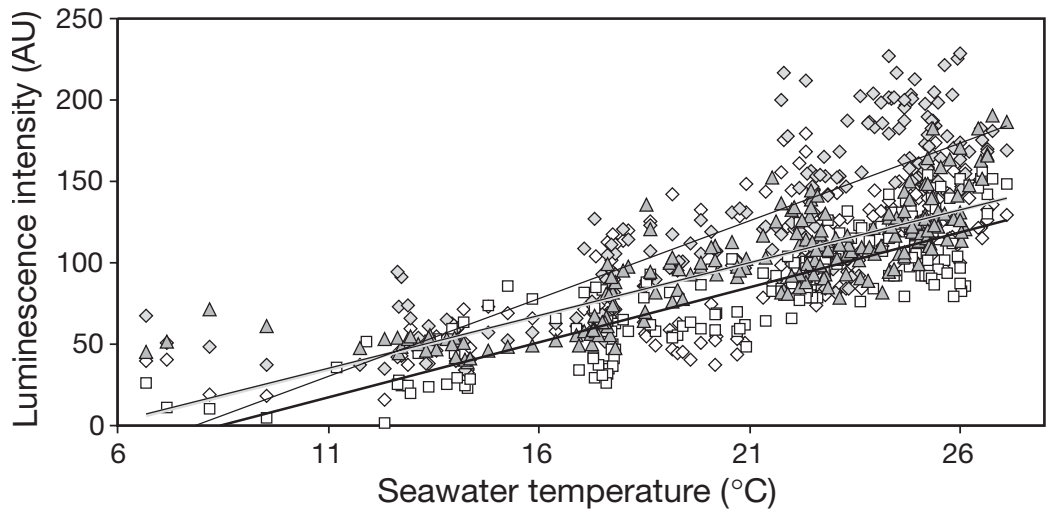

Fig. 7. Crassostrea gigas. Scattergrams of luminescence intensity (arbitrary units, AU) against water temperature for 4 shells. Luminescence intensity was obtained from line-plot profile in calcitic shells of oysters (Fig. 6a) 
Table 2. Crassostrea gigas. (a) Ordinary least-square regressions of water temperature $\left(T_{1}^{\circ}{ }^{\circ} \mathrm{C}\right.$ ) against luminescence intensity (LI) in 4 shells (SH1, SH2, SH3, SH4) of oysters from Thau lagoon; (b) Tests for homogeneity of slopes and elevations of significant regressions compared among shells by analysis of covariance. $\mathrm{N}$ : sample size

\begin{tabular}{|c|c|c|c|c|c|}
\hline (a) & $\mathrm{N}$ & Regression & $\mathrm{r}^{2}$ & $F$ & $\mathrm{p}$ \\
\hline SH1 & 200 & $\mathrm{LI}=-57.295+6.765 \cdot T_{,}^{\circ} \mathrm{C}(1)$ & 0.723 & 520.90 & $<0.0001$ \\
\hline SH2 & 202 & $\mathrm{LI}=-36.870+6.510 \cdot T^{\circ} \mathrm{C}(2)$ & 0.577 & 270.03 & $<0.0001$ \\
\hline SH3 & 202 & $\mathrm{LI}=-74.812+9.557 \cdot T^{\circ}{ }^{\circ} \mathrm{C}(3)$ & 0.672 & 410.17 & $<0.0001$ \\
\hline SH4 & 202 & $\mathrm{LI}=-36.221+6.506 \cdot T^{\circ}{ }^{\circ} \mathrm{C}(4)$ & 0.694 & 453.56 & $<0.0001$ \\
\hline \multicolumn{6}{|l|}{ (b) } \\
\hline Slope & df & SS & MS & $F$ & $\mathrm{p}$ \\
\hline (1) vs. (2) vs. (3) vs. (4) & 3 & 25316.06 & 8438.69 & 15.84 & $<0.0001$ \\
\hline (1) vs. (2) vs. (4) & 2 & 168.75 & 84.38 & 0.16 & 0.8535 \\
\hline$(1,2,4)$ vs. $(3)$ & 1 & 25171.41 & 25171.41 & 47.26 & $<0.0001$ \\
\hline (1) vs. (2) & 1 & 122.56 & 122.56 & 0.23 & 0.6316 \\
\hline (1) vs. (3) & 1 & 15019.14 & 15019.14 & 28.20 & $<0.0001$ \\
\hline (1) vs. (4) & 1 & 129.25 & 129.25 & 0.24 & 0.6224 \\
\hline (2) vs. (3) & 1 & 17422.60 & 17422.60 & 32.71 & $<0.0001$ \\
\hline (2) vs. (4) & 1 & 0.03 & 0.03 & 0.00 & 0.9943 \\
\hline (3) vs. (4) & 1 & 17876.16 & 17876.16 & 33.56 & $<0.0001$ \\
\hline \multicolumn{6}{|l|}{ Elevation } \\
\hline (1) vs. (2) vs. (3) vs. (4) & 3 & 8426.77 & 2808.92 & 5.27 & 0.0013 \\
\hline (1) vs. (2) vs. (4) & 2 & 2390.66 & 1195.33 & 2.24 & 0.1067 \\
\hline$(1,2,4)$ vs. $(3)$ & 1 & 6090.85 & 6090.86 & 11.43 & 0.0008 \\
\hline (1) vs. (2) & 1 & 1669.64 & 1699.65 & 3.19 & 0.0744 \\
\hline (1) vs. (3) & 1 & 1279.76 & 1279.76 & 2.40 & 0.1215 \\
\hline (1) vs. (4) & 1 & 1862.96 & 18692.96 & 3.50 & 0.0618 \\
\hline (2) vs. (3) & 1 & 5820.80 & 5820.80 & 10.93 & 0.0010 \\
\hline (2) vs. (4) & 1 & 1.71 & 1.71 & 0.00 & 0.9548 \\
\hline (3) vs. (4) & 1 & 6198.54 & 6198.54 & 11.64 & 0.0007 \\
\hline
\end{tabular}

tissues and a preferential accumulation in the calcified parts, as shown for C. virginica (Carriker et al. 1980b, Huanxin et al. 2000). Oysters from the genus Crassostrea have a very thin periostracum (Carriker et al. 1980a), and the pallial retractor muscles that connect the ventral lobe of the mantle to the shell are few and

Table 3. Crassostrea gigas. (a) Ordinary least square regressions of dissolved oxygen concentration $\left(\mathrm{O}_{2}\right)$ against luminescence intensity (LI) in 4 shells (SH1, SH2, SH3, SH4) of oysters from Thau lagoon; (b) Tests for homogeneity of slopes and elevations of significant regressions compared by analysis of covariance. ns: non-significant, $\mathrm{p}>0.05$; ${ }^{* *} 0.001<\mathrm{p} \leq 0.05 ;{ }^{* * *} \mathrm{p}<0.001 ; \mathrm{N}$ : sample size

\begin{tabular}{|lccccc|}
\hline $\begin{array}{l}\text { (a) } \\
\text { Shell }\end{array}$ & Regression & $\mathrm{r}^{2}$ & $F$ & $\mathrm{~N}$ \\
\hline $\mathrm{SH} 1$ & $\mathrm{LI}=155.403-9.825 \cdot \mathrm{O}_{2}$ & $(1)$ & 0.487 & $18.98^{* * *}$ & 22 \\
$\mathrm{SH} 2$ & $\mathrm{LI}=159.791-8.767 \cdot \mathrm{O}_{2}$ & $(2)$ & 0.398 & $13.25^{* *}$ & 22 \\
$\mathrm{SH} 3$ & $\mathrm{LI}=197.353-11.243 \cdot \mathrm{O}_{2}$ & $(3)$ & 0.389 & $13.95^{* *}$ & 24 \\
SH4 & $\mathrm{LI}=155.803-8.129 \cdot \mathrm{O}_{2}$ & $(4)$ & 0.340 & $12.40^{* *}$ & 26 \\
(b) & & & & \\
Slope & (1) vs. (2) vs. (3) vs. (4) & & $0.75 \mathrm{~ns}$ & \\
Elevation & (1) vs. (2) vs. (3) vs. (4) & & $2.48 \mathrm{~ns}$ & \\
\hline
\end{tabular}

thin (no pallial line) (Stenzel 1971). Consequently, the extrapallial cavity is not well isolated from the seawater when the valves are opened. This probably facilitated direct transfer of $\mathrm{Mn}^{2+}$ from the marking bath to the extrapallial fluid and to the site of mineralization, which would explain the short lag times observed.

For other marine bivalves with a more isolated extrapallial cavity, Mn marking may not prove so efficient. Manganese was used for marking shells of the abalone Haliotis rubra by Hawkes et al. (1996), but under more restrictive conditions - a higher concentration (50 ppm) and longer immersion time ( $48 \mathrm{~h}$ ) than in our study. In freshwater bivalves, their better regulation of the trace metal composition of the extrapallial fluid compared to marine bivalves (Wada \& Fujinuki 1976) would lead to reduced efficiency of $\mathrm{Mn}$ marking. A lag phase and equilibration period of up to several days was reported for the freshwater bivalve Hyridella depressa experimentally exposed to elevated water concentrations of $\mathrm{Mn}^{2+}$ (20 ppm) for 2 to $6 \mathrm{~d}$ by Jeffree et al. (1995).

Other chemical markers that bind to calcium during shell mineralization, such as fluorochromes, calcein or tetracycline analogues, have been used to create bright lines in bivalve shells when observed under 
fluorescence microscopy (Day et al. 1995, Kaehler \& McQuaid 1999, Sato-Okoshi \& Okoshi 2002). However, marking methods with fluorochromes often require a relatively long exposure time (12 to $48 \mathrm{~h}$ ) to produce discernible marks (Day et al. 1995, Sato-Okoshi \& Okoshi 2002) and/or high concentrations of the markers, and this may lead to substantial mortality (e.g. with tetracycline and also calcein: Day et al. 1995). Moreover, fluorochromes can be expensive, and there can be difficulty in distinguishing induced growth marks from naturally occurring autofluorescence (see Day et al. 1995, Kaehler \& McQuaid 1999) or due to contamination of the external shell layers (Kaehler \& McQuaid 1999). Fujikura et al. (2003) used strontium chloride $\left(\mathrm{SrCl}_{2}\right)$ to mark the clam Ruditapes philippinarum, and this produced enriched Sr layers visible as bright bands in the back-scattered electron image under scanning electron microscopy. Although their method was effective in detecting microscopic increases in shell growth, the immersion time in the Sr chloride solution (from 17 to $24 \mathrm{~h}$ ) led to substantial mortality. Thus, compared to methods using other chemical markers, the Mn marking method appears to be more convenient and specifically well adapted to biomineralization processes. However, further experiments should be performed on other bivalve species to confirm the rapid transfer of $\mathrm{Mn}^{2+}$ to the mineralization site and the reliability of the marking procedure, especially in freshwater bivalves.

Beyond the Mn marking method itself, our CL analysis revealed the shell hinge as a very suitable marking area, since it records the whole shell history of Crassostrea gigas reared in Thau lagoon. Moreover, the relationship between hinge growth and shell length growth was found to be linear $\left(\mathrm{r}^{2}=0.71\right.$ in Langlet 2002). Our method, which combines Mn markings and analysis of seasonal variations in luminescence intensity in the hinge, offers new opportunities for determining age and growth patterns of wild populations of C. gigas.

\section{Simultaneous deposition of various calcitic structure and $\mathrm{CaCO}_{3}$ polymorphs}

The luminescent marking lines were very informative as to the carbonate deposition process in the shell of Crassostrea gigas. On the one hand, luminescent marking lines were visible across the whole shell, indicating unambiguously the presence of growth layers and also growth direction (Fig. 3); on the other hand, they provided evidence that both foliated and chalky calcite microstructures (Figs. 2 \& 3a) were deposited simultaneously. The foliated bands were probably secreted during the summer (bright orange-red lumi- nescence) and winter (dark blue luminescence). Thus, neither of these calcite structures are useful as sclerochronologic markers (i.e. as independent markers of seasonal growth in the shell of $C$. gigas). This agrees with the conclusions of Surge et al. (2001) who, in contrast to seasonal variations in isotopic composition, found no seasonal pattern for the translucent growth bands in the shell of the American oyster C. virginica. The distribution of these 2 forms of calcite may have a structural purpose rather than reflecting a seasonal pattern of shell growth (Surge et al. 2001). The dense foliated calcite may ensure the solidity of the shell, whereas the porous chalky calcite may allow the rapid adaptation of shell shape to the substratum on which the bivalve settles (Carriker et al. 1980a). Finally, the 2 carbonate polymorphs calcite and aragonite were probably secreted simultaneously, as indicated by the changing wavelength of the marker lines from $620 \mathrm{~nm}$ in the hinge area (calcite) to $540 \mathrm{~nm}$ in the ligament (partly aragonite: Stenzel 1962). Our results confirm the usefulness of CL analysis in revealing the complex functioning of the mantle epithelium with respect to carbonate deposition on a microscale (Hawkes et al. 1996).

\section{Variations in natural luminescence intensity at daily and tidal scales}

Our results indicate that the pair of natural luminescent lines with the adjacent purple-blue line (nonluminescent line) is deposited daily. The terminology 'luminescent increment' will be used here to describe this daily growth unit observed under cathodoluminescence of Crassostrea gigas. Microgrowth increments have been described as daily increments (light-dark cycle) in intertidal and subtidal shells (Lutz \& Rhoads 1980 [review], Richardson 1996). Other studies have pointed out the predominance of sub-daily rhythms within the shell of bivalves (see Cerrato 2000 for review), reflecting a tidal rather than a light-dark cycle. Thus, it seems reasonable to attribute a semi-diurnal frequency to each luminescent or non-luminescent line deposited in the hinge of $C$. gigas in Thau lagoon. However, it is difficult to discriminate between tidal influences and the influence of the circadian cycle (Bourget et al. 1991). A deposition rhythm of approximately 1 ring per tidal cycle was shown for $C$. virginica (Palmer \& Carriker 1979) and C. gigas in the field (Piquet 1994). Each luminescent increment in the present study may be similar to the pair of semi-diurnal increments (defined on the basis of increment transparency) separated from each other by a diffuse rather than a distinct boundary that have been described for other bivalves (Richardson 1987, 1996, Cerrato 2000). 
At a daily scale, transparency has been clearly correlated with metabolic rate and rapid changes in water temperature (Lewis \& Cerrato 1997). The similarity between the transparency and luminescence contrasts in the shell at the microscale suggests that CL analysis (a chemical analysis) may provide new insights into the physiological processes of depositional mechanisms.

In the shell, daily variations in the organic matter content of the Ca-carbonate may control the daily variations in luminescence intensity by varying the proportion of sites of $\mathrm{Ca}^{2+}$ substitution by $\mathrm{Mn}^{2+}$. The alternation of $\mathrm{Ca}$ carbonate-rich layers and organic-rich layers at a $10 \mu \mathrm{m}$ scale, attributed to daily or sub-daily variations in shell growth, has been well documented for numerous species of bivalves (Gordon \& Carriker 1978, Lutz \& Rhoads 1980, Bourget et al. 1991). These changes are classically interpreted as reflecting periods of shell deposition and shell dissolution, which occur during aerobic and anaerobic respiration, respectively (Lutz \& Rhoads 1977). In the intertidal zone, rhythmic shell closure during low tide results in such growth structures (Gordon \& Carriker 1978). In Thau lagoon, oysters are continuously immersed, and periodic shell closure has never been observed. However, an endogenous cycle may control the formation of growth increments, with a semi-diurnal periodicity as suggested for other bivalves (Cenni et al. 1990, Richardson 1996), and thus may control the daily variations in luminescence intensity of Crassostrea gigas shells.

Alternatively, daily variations in Mn bioavailability in seawater may affect the $\mathrm{Mn}^{2+}$ content of the oyster's shell. The daily cycle of sunlight intensity has been shown to directly affect the $\mathrm{Mn}^{2+}$ concentration in surface seawater by photoinhibiting manganese oxidizing microorganisms (Sunda \& Huntsman 1990). In contrast, sunlight has been shown to exert a stimulatory effect on the reductive dissolution of natural Mn oxides produced by microbial activity in seawater (Sunda \& Huntsman 1994). Such mechanisms involving photoperiod are conceivable in a shallow semi-confined environment such as Thau lagoon, where the hydrodynamic flow is reduced by the presence of the shellfish farms.

At an intermediate temporal scale ( $>1 \mathrm{~d})$, spectral analysis of the luminescence revealed periodicities of close to $7 \mathrm{~d}$ each (Table 1 ) that may reflect tidal patterns (lunar phase, fortnightly tidal cycles, spring and neap tides). Kennish (1980) has shown, in the shell of Mercenaria mercenaria that sub-millimetric growth marks are organized into cycles of decreasing and overlapping periods, with groups of about 30 marks reflecting high spring and low neap tides (29 d), and sub-divisions into groups of 6 to 8 marks corresponding to an approximately fortnightly cycle: neap and spring tide (14 d). In other studies, pairs of sub-daily increments based on shell transparency often fluctuated from strong to weak over a fortnightly period, although little or no change in increment width was observed (see Cerrato 2000 for review).

In Thau lagoon, lunar phases may exert some influence through increased seawater renewal during spring tides and a concomitant variation in the physicochemical characteristics of the water. The variations in the dissolved oxygen concentrations observed in Thau lagoon may reflect the influence of lunar cycles. These variations may affect the processes involved in the biomineralization and incorporation of $\mathrm{Mn}^{2+}$ in Crassostrea gigas shells.

\section{Role of water temperature and Mn bioavailability in seasonal patterns of natural luminescence}

In summer, the high water temperature recorded in Thau lagoon was associated with both an increase in $\mathrm{Mn}^{2+}$ concentrations in the oyster shells, reflected in CL intensity (Figs. 3 \& 6) and a high shell growth rate (Alunno-Bruscia et al. 2001, Gangnery et al. 2003). This suggests that water temperature mainly controls shell luminescence, influencing both the rate of cation transfer from the water to the site of mineralization in the shell and Mn bioavailability in the surrounding water.

Water temperature is known to modulate both shell growth (Héral et al. 1984) and the biomineralization process in bivalve shells through biological control (Wheeler 1992). For instance, shell transparency (observed from thin sections) was shown to vary on a seasonal as well as a short time-scale basis as a result of seasonal changes in bottom-water temperature (Lewis \& Cerrato 1997). Stimulation by temperature of the biomineralization processes (i.e. rate of shell deposition) increases the rate of $\mathrm{Ca}$ turnover in the oyster mantle (see Wheeler 1992). As the bulk of shell calcium comes originates from the external medium, $\mathrm{Ca}^{2+}$ is actively transported from the seawater to the extrapallial fluid during shell deposition (Wilbur \& Saleuddin 1983). It has been demonstrated that $\mathrm{Mn}^{2+}$ is used as an analog of $\mathrm{Ca}^{2+}$ in the uptake of cations from the external medium (Markich \& Jeffree 1994, Markich et al. 2001). Thus, a rise in water temperature may increase $\mathrm{Mn}^{2+}$ uptake and its transfer to the site of shell deposition, resulting in higher concentrations in the growth layers. This agrees with the results of Wada \& Fujinuki (1976), who showed that the $\mathrm{Mn}^{2+}$ concentration in the extrapallial fluid of Crassostrea gigas was higher $(\approx 0.21 \mathrm{ppm})$ during periods of active shell growth than during periods of low growth $(\approx 0.15 \mathrm{ppm})$. In the same way, $\mathrm{Mn}^{2+}$ concentrations in the extra- 
pallial fluid of C. gigas from Thau lagoon probably increased during active shell growth in summer, resulting in high $\mathrm{Mn}^{2+}$ concentrations in the relevant growth layers.

Water temperature, combined with other abiotic and biotic factors, probably influenced the form of manganese and its bioavailability to filter feeders. Dissolved manganese $\mathrm{Mn}^{2+}$ is considered the most bioavailable form for bivalves ('Free Ion Model': Campbell 1995). The relative balance between $\mathrm{Mn}^{2+}$ oxidation and Mn oxide reduction (Mn bioavailability) is largely controlled by the concentration of dissolved $\mathrm{O}_{2}$, the solubility of which is temperature-dependent. In our study, dissolved $\mathrm{O}_{2}$ concentration and $\mathrm{pH}$ decreased from May to August 1999 during periods of rising temperatures (Alunno-Bruscia et al. 2001). In Thau lagoon, which supports intensive shellfish culture, water temperature has a great influence on the development of hypoxic or anoxic conditions because of the lagoon's low tidal range and its narrow connection with the sea, which limits water renewal and resuspension of organic-rich sediments (Souchu et al. 1998). Sediments in the study area consist of more than $80 \%$ of thin particles (silts $<63 \mu \mathrm{m}$ ), and contain a large proportion of organic matter (Pena \& Picot 1991). The silt fraction has a large adsorption surface and its richness in colloidal particles possibly traps trace elements under oxic conditions (Kessick \& Morgan 1975, Boulègue et al. 1978). Moreover, organic matter is involved in biogeochemical cycles, especially in the speciation of redox-sensitive elements such as Mn. A rise in temperature lowers the solubility of $\mathrm{O}_{2}$ and its concentration in water by increasing the metabolic consumption of $\mathrm{O}_{2}$ by living organisms. In the sediments, it also stimulates the activity of heterotrophic bacteria, which catalyze the reduction of Mn-oxides (non-soluble $\mathrm{MnO}_{2}$ or $\left.\mathrm{Mn}(\mathrm{OH})_{\mathrm{x}}\right)$ that comprise a source of oxygen for degradation of organic matter (Sundby et al. 1986, Souchu et al. 1998). These conditions favor the reduction and dissolution of the Mn-oxides or $\mathrm{Mn}^{2+}$ bound to biological debris that are trapped in the sediments. Large amounts of $\mathrm{Mn}^{2+}$ may then be released into the water column, as shown by Fernex et al. (1984) for the NW Mediterranean shelf. In fall and winter, however, water temperature decreases, important rainfall occurs (about $64 \%$ of the total rainfall was recorded from September 1999 to January 2000: Alunno-Bruscia et al. 2001), and waters are mixed due to strong winds and periodic storms; this results in oxic conditions which favor the trapping of $\mathrm{Mn}^{2+}$ in the sediments. Dissolved $\mathrm{Mn}$ is then less available, which may explain why, in the present study, the experimental marking lines were less intense in Crassostrea gigas shells in October 1999 when the water temperature was about $17^{\circ} \mathrm{C}$. Combined with the concomitant reduction in growth of oyster shell length observed between September and October 1999 (Alunno-Bruscia et al. 2001), this may have reduced both the uptake of $\mathrm{Mn}^{2+}$ and the number of potential sites of $\mathrm{Mn}$ incorporation into the carbonates, thus decreasing the efficiency of Mn-marking in the fall.

\section{Further applications of Mn marking method}

The present method, which combines Mn markings and analysis of the temporal variations of luminescence intensity in the hinge of oysters, has numerous applications of significant interest to various research fields. In bioenergetics and biology, it could be applied in quantifying the rate of carbonate deposition on a daily and a seasonal scale and, combined with other data on shell transparency (Lewis \& Cerrato 1997) or shell chemistry (Lorrain et al. 2005), be used to estimate the energetic costs related to biomineralization processes and shell construction or repair. This could be very helpful in refining bioenergetics models for bivalves (e.g. Bayne \& Newell 1983). Moreover, cathodoluminescence could be used to determine age in Crassostrea gigas, and thus provide data critical for estimating growth patterns, recruitment, and survivorship of wild populations of oysters (Cardoso et al. in press): CL investigations on C. gigas shells along the European Atlantic coasts (from Portugal to The Netherlands) have revealed variations in color and intensity of luminescence, although the contrasts are lower than those in Thau lagoon. Low CL intensity in shells from intertidal areas is consistent with a very low concentration of dissolved $\mathrm{Mn}$ in oxygenated seawater. Our method could have significant implications in ecotoxicology and biomonitoring. In coastal or estuarine waters and sediments, manganese is involved in many biogeochemical redox processes involving carbon degradation, which directly affect cycles of toxic elements such as mercury and sulfate (Hines et al. 1997, Quemerais et al. 1998). The Mn-induced luminescence in the shell of bivalves used as bioindicators could improve the monitoring of water quality and nutrient cycling, and also provide valuable data on oxygen concentrations or temperature in bottom or pore waters. Finally, the method could find applications in paleoecology, paleontology and archeology. Combined with other chemical proxies (Surge et al. 2003), CL could help elucidate variations in hydrological parameters of past environments recorded in shells. In archeological studies, it could provide information on shellfish collection in relation to the use of coastal resources and their role in the economy of ancient human settlements (for instance, shell middens, that are found in coastal zones worldwide). Both Ostrea edulis from Gallo- 
Roman sites and fossil oysters from Jurassic stratigraphic levels have shown differences in background luminescence intensity that probably reflect seasonal growth rate or paleotemperature variations and also indicate the season of death (Langlet 2002).

Acknowledgements. We thank J.M. Chabirand, J. Oheix, and C. Vercelli for their help in the field and in the laboratory. We are grateful to J.M. Guarini and G. Daigle for their help with statistical analysis and to D. Delors and P. Blanc, for assistance with shell preparation and cathodoluminescence analysis, respectively. This paper benefited from very helpful comments by M. Fréchette and P. Souchu. R. Day and 2 anonymous referees are thanked for reviewing the manuscript.

\section{LITERATURE CITED}

Alunno-Bruscia M, Vercelli C, Chabirand JM, Oheix J, Buestel D (2001) Influence de la densité d'élevage sur la croissance et la qualité de l'huître creuse Crassostrea gigas dans l'étang de Thau. Rapport interne IFREMER DRV/ RA/LCM, 2001-06

Barbin V (2000) Cathodoluminescence of carbonate shells: biochemical vs. diagenetic process. In: Pagel M, Barbin V, Blanc P, Ohnenstetter, D (eds) Cathodoluminescence in geosciences. Springer-Verlag, Berlin, p 303-329

Bayne, BL, Newell, RC, (1983) Physiological energetics of marine molluscs. In: Saleuddin ASM, Wilbur KM (eds) The Mollusca. Academic Press, New York, p 407-515

Boulègue J, Renard D, Michard G, Boulad AP, Chantret F (1978) Manganese dioxide concretions on granite outcrops in an intertidal area (cove of Belmont, France) II. Rapid dioxide formation during the mixing of freshwater and seawater. Chem Geol 23:41-63

Bourget E, Bérard H, Brock V (1991) Testing hypotheses concerning the formation of shell growth marks in marine pelecypods. Can J Zool 69:535-546

Campbell PGC (1995) Interactions between trace metals and organisms: critique of the free-ion activity model. In: Tessier A, Turner D (eds) Metal speciation and bioavailability in aquatic systems. J Wiley \& Sons, Chichester, p 45-102

Cardoso JF, Langlet D, Loff JF, Martins AR, Witte JI, Santos PT, Van der Veer HW (in press) Spatial variability in growth and reproduction of the Pacific oyster Crassostrea gigas (Thunberg 1793) along the west European coast. J Sea Res

Carriker MR, Palmer RE, Prezant RS (1980a) Functional ultramorphology of the dissochonch valves of the oyster Crassostrea virginica. Proc Natl Shellfish Assoc 70:139-183

Carriker MR, Palmer RE, Sick LV, Johnson CC (1980b) Interaction of mineral elements in sea water and shell of oysters (Crassostrea virginica) cultured in controlled and natural systems. J Exp Mar Biol Ecol 46:279-296

Cenni S, Cerrato RM, Siddall SE (1990) Periodicity of growth lines in larval and postlarval shells of Mercenaria mercenaria. J Shellfish Res 8:444-445

Cerrato RM (2000) What fish biologists should know about bivalve shells. Fish Res 46:39-49

Day RW, Williams MC, Hawkes GP (1995) A comparison of fluorochromes for marking abalone shells. Mar Freshw Res 46:599-605

El Ali A, Barbin V, Calas G, Cervelle B, Ramseyer K, Bouroulec J (1993) $\mathrm{Mn}^{2+}$ activated luminescence in dolomite, cal- cite and magnesite: quantitative determination of manganese site distribution by EPR and CL spectroscopy. Chem Geol 104:189-202

Fernex FE, Span D, Flatau GN, Renard D (1986) Behavior of some metals in surficial sediments of the Northwest Mediterranean continental shelf. In: Sly PG (ed) Proc 3rd Int Symp Interactions Between Sediments and Water. Springer Verlag, New York, p 353-370

Fujikura K, Okoshi K, Naganuma T (2003) Strontium as a marker for estimation of microscopic growth rates in a bivalve. Mar Ecol Prog Ser 257:295-301

Gangnery A, Chabirand JM, Lagarde F, Le Gall P, Oheix J, Bacher C, Buestel D (2003) Growth model of the Pacific oyster, Crassostrea gigas, cultured in Thau lagoon (Méditerranée, France). Aquaculture 215:267-290

Gordon J, Carriker MR (1978) Growth lines in a bivalve mollusk: subdaily patterns and dissolution of the shell. Science 202:519-521

Hawkes GP, Day RW, Wallace MW, Nugent KW, Bettiol AA, Jamieson DN, Williams MC (1996) Analyzing the growth and form of mollusc shell layers, in situ, by cathodoluminescence microscopy and Raman spectroscopy. J Shellfish Res 15:659-666

Héral M, Deslous-Paoli JM, Razet JM, Prou J (1984) Essais de mise en évidence in situ de paramètres biotiques et abiotiques de l'eau et de l'interface eau-sédiment intervenant dans la production de l'huître Crassostrea gigas. Oceanus 10:465-475

Hines ME, Faganeli J, Planinc R (1997) Sedimentary anaerobic microbial biogeochemistry in the Gulf of Trieste, northern Adriatic Sea: influences of bottom water oxygen depletion. Biogeochemistry 39:65-86

Hood DW (1972) Seawater chemistry. In: Fairbridge RW (ed) Encyclopedia of geochemistry and environmental science. Van Norstand Reinhold, New York, p 1062-1070

Huanxin W, Lejun Z, Presley BJ (2000) Bioaccumulation of heavy metals in oyster (Crassostrea virginica) tissue and shell. Environ Geol 39:1216-1226

Huitema BE (1980) The analysis of covariance and alternatives. J Wiley \& Sons, New York

Jeffree RA, Markich SJ, Lefebvre F, Thellier M, Ripoll C (1995) Shell microlaminations of the freshwater bivalve Hyridella depressa as an archival monitor of manganese water concentration: experimental investigation by depth profiling using secondary ion mass spectrometry. Experientia 51:838-848

Kaehler S, McQuaid CD (1999) Use of the flurochrome calcein as an in situ growth marker in the brown mussel Perna perna. Mar Biol 133:455-460

Kennish MJ (1980) Shell microgrowth analysis: Mercenaria mercenaria as a type example for research in population dynamics. In: Rhoads DC, Lutz RA (eds) Skeletal growth of aquatic organisms. Plenum Press, New York, p 255-295

Kessick MA, Morgan JJ (1975) Mechanism of autoxidation of manganese in aqueous solution. Environ Sci Technol 9:157-159

Langlet D (2002) Enregistrement à haute fréquence des conditions environnementales par les tests de bivalves. Application des techniques de marquage, cathodoluminescence et chimie à l'huître creuse Crassostrea gigas de l'étang de Thau (Hérault, France). PhD thesis, Université P\&M Curie, Paris

Lewis DE, Cerrato RM (1997) Growth uncoupling and the relationship between shell growth and metabolism in the soft shell clam Mya arenaria. Mar Ecol Prog Ser 158: 177-189 
Lorrain A, Gillikin DP, Paulet YM, Chauvaud L, Le Mercier A, Navez J, André L (2005) Strong kinetic effects on Sr/Ca ratios in the calcitic bivalve Pecten maximus. Geology 33:965-968

Lutz RA, Rhoads DC (1977) Anaerobiosis and a theory of growth line formation. Science 198:1222-1227

Lutz RA, Rhoads DC (1980) Growth patterns within the molluscan shell, an overview. In: Rhoads DC, Lutz RA (eds) Skeletal growth of aquatic organisms. Plenum Press, New York, p 203-254

Markich SJ, Jeffree RA (1994) Absorption of divalent trace metals as analogues of calcium by Australian freshwater bivalves: an explanation of how water hardness reduces metal toxicity. Aquat Toxicol (Amsterdam) 29:257-290

Markich SJ, Brown PL, Jeffree RA (2001) Divalent metal accumulation in freshwater bivalves: an inverse relationship with metal phosphate solubility. Sci Total Environ 275:27-41

Pagel M, Barbin V, Blanc P, Ohnenstetter D (eds) (2000) Cathodoluminescence in geosciences. Springer-Verlag, Berlin

Paillard D, Labeyrie L, Yiov P (1996) Macintosh program performs time-series analysis. EOS Trans Am Geophys Union:379

Palmer RE, Carriker MR (1979) Effects of cultural conditions on morphology of the shell of the oyster Crassostrea virginica. Proc Natl Shellfish Assoc 69:58-72

Peck LS, Baker AC, Conway LZ (1996) Strontium labelling of the shell of the Antarctic limpet Nacella concinna (Strebel, 1908). J Molluscan Stud 62:315-325

Pena G, Picot B (1991) Métaux traces dans les sédiments d'une lagune méditerranéenne: l'étang de Thau. Oceanol Acta14:459-472

Petelet E, Ben Othman D, Luck JM (1997) Etude des charges dissoute et particulaire dans une rivière méditerranéenne (Vène, Hérault, France): apport des éléments majeurs, traces et des isotopes du plomb et du strontium sur l'origine et la circulation des eaux et des charges transportées. C R Acad Sci Sér 2a 324:753-761

Piquet E (1994) Analyse des données hydrobiologiques et biométriques obtenues dans le cadre du contrôle des performances des populations diploïdes et triploïdes de Crassostrea gigas. Corrélations avec les observations réalisées en cathodoluminescence. MSc dissertation, Université Reims, France

Quemerais B, Cossa D, Rondeau B, Pham TT, Fortin B (1998) Mercury distribution in relation to iron and manganese in the waters of the St. Lawrence river. Sci Total Environ 213:193-201

Rafélis M, Renard M, Emmanuel L, Durlet C (2000) Apport de la cathodoluminescence à la connaissance de la spéciation du manganèse dans les carbonates pélagiques. C R Acad Sci Sér 2a 330:391-398

Rhoads DC, Lutz RA (1980) Skeletal growth of aquatic organisms. Plenum Press, New York

Richardson CA (1987) Tidal bands in the shell of the clam Tapes philippinarum. Proc R Soc Lond B 230:367-387

Richardson CA (1996) Exogenous or endogenous control of growth band formation in subtidal bivalve shells. Bull Inst Océanogr 14:133-141

Editorial responsibility: Otto Kinne (Editor-in-Chief) Oldendorf/Luhe, Germany
Richardson CA, Collis SA, Ekaratne K, Dare P, Key D (1993) The age determination and growth rate of the European flat oyster, Ostrea edulis, in British waters determined from acetate peels of umbo growth lines. ICES J Mar Sci 50:493-500

Rosenberg GD, Hugues WW (1991) A metabolic model for the determination of shell composition in the bivalve mollusc, Mytilus edulis. Lethaia 24:83-96

Sato-Okoshi W, Okoshi K (2002) Application of fluorescent substance to the analysis of growth performances in Antarctic bivalve, Latternulla elliptica. Polar Biosci 15: 66-74

Schein E, Roux M, Barbin V, Chiesi F, Renard M, Rio M (1991) Enregistrement des paramètres écologiques par la coquille des bivalves: approche pluridisciplinaire. Bull Soc Geol Fr 162:687-698

Souchu P, Gasc A, Collos Y, Vaquer A, Tournier H, Bibent B, Deslous-Paoli JM (1998) Biogeochemical aspects of bottom anoxia in a Mediterranean lagoon (Thau, France). Mar Ecol Prog Ser 164:135-146

Stenzel HB (1962) Aragonite in the resilium of oysters. Science 136:1121-1122

Stenzel HB (1963) Aragonite and calcite as constituents of adult oyster shells. Science 142:232-233

Stenzel HB (1971) Oysters. In: Moore RC (ed) Treatise on invertebrate paleontology, Part N, Vol. 3. Geological Society of America, Boulder CO, p N953-N1224

Strom A, Francis FR, Mantua NJ, Miles EL, Peterson DL (2004) North Pacific climate recorded in growth rings of geoduck clams: a new tool for paleoenvironmental reconstruction. Geophys Res Lett 31:L06206

Sunda WG, Huntsman SA (1990) Diel cycles in microbial manganese oxidation and manganese redox speciation in coastal waters of the Bahama Islands. Limnol Oceanogr 35:325-338

Sunda WG, Huntsman SA (1994) Photoreduction of manganese oxides in seawater. Mar Chem 46:133-152

Sundby B, Anderson LG, Hall POJ, Iverfeldt A, Rutgers van der Loeff MM, Westerlund SFG (1986) The effect of oxygen on release and uptake of cobalt, manganese, iron and phosphate at the sediment-water interface. Geochim Cosmochim Acta 50:1281-1288

Surge D, Lohmann KC, Dettman DL (2001) Controls on isotopic chemistry of the American oyster, Crassostrea virginica: implications for growth patterns. Palaeogeogr Palaeoclimatol Palaeoecol 172:283-296

Surge D, Lohmann KC, Goodfriend GA (2003) Reconstructing estuarine conditions: oyster shells as recorders of environmental changes, Southwest Florida. Estuar Coast Shelf Sci 57:737-756

Wada I, Fujinuki (1976) Biomineralisation in bivalves molluscs with emphasis on the chemical composition of extrapallial fluid. In: Watabe N, Wilbur KM (eds) The mechanisms of mineralization in invertebrates and plants. University of South Carolina Press, Columbia, p 175-190

Wheeler AP (1992) Mechanisms of molluscan shell formation. In: Bonucci E (ed) Calcification in biological systems. CRC Press, Boca Raton, FL, p 179-215

Wilbur KM, Saleuddin ASM (1983) Shell formation. In: Saleuddin ED, Wilbur KM (eds) The Mollusca: physiology, Part 1, Vol 4. Academic Press, New York, p 236-288

Submitted: March 3, 2005; Accepted: January 12, 2006

Proofs received from author(s): June 21, 2006 